\title{
Effect of Particle Size and Adsorbed Water on Sintering of Calcium Fluoride
}

\author{
By \\ Susumu MIZUTA* and Hiroaki YANAGIDA \\ ( Department of Industrial Chemistry, University of Tokyo \\ * Present Address; National Chemical Laboratory for Industry
}

\section{Introduction}

The first investigation on sintering of alkali fluorides and alkali-earth fluorides was performed by Allison and Murray ${ }^{1)}$ in 1954. Measuring the shrinkage rate of initial sintering in the temperature range between 500 and $1000^{\circ} \mathrm{C}$ on $\mathrm{CaF}_{2}, \mathrm{BaF}_{2}$ and $\mathrm{CeF}_{3}$, they interpreted those data on the standpoint of plastic flow mechanism.

Theories for the viscous flow and plastic flow during sintering and those rate equations were proposed in the days of 1945 through 1950 by Frenkel $^{2)}$ (for Newtonian flow), Clark and White ${ }^{3)}$ (for Bingham flow) and Shutlleworth and Mackenzie 4) (for shrinkage of pores in the sintered bodies).

Allison and Murray analyzed their experimental data with those rate equations, where linear relation was found between the raito of the particle size $\left(r_{\mathrm{A}} / r_{\mathrm{B}}\right)$ and the times necessary to accomplish a given fractional shrinkage $\left(t_{\mathrm{A}} / t_{\mathrm{B}}\right)$ in two different powder compacts $\mathrm{A}$ and $\mathrm{B}$ as follows

$$
t_{\mathrm{A}} / t_{\mathrm{B}}=r_{\mathrm{A}} / r_{\mathrm{B}}
$$

According to Herring's scale law ${ }^{5}$ the linear relation is to be observed for plastic flow process, while for diffusion process the cubic relation $\left(t_{\mathrm{A}} / t_{\mathrm{B}}=\right.$ $\left.\left(r_{\mathrm{A}} / r_{\mathrm{B}}\right)^{3}\right)$ should hold. Plastic flow mechanism was thus adopted by Allison and Murray.

In 1949 another theory for an atom-by-atom diffusion process was proposed by Pines $^{6)}$ and Kuczynsk $\mathrm{i}^{7)}$ where shrinkage was considered as a result of the diffusion of vacancies from an inner pore to the free surface of the specimen. Upon this diffusion model Mackenzie and Shutlleworth pointed out that a shrinkage rate in the diffusion process would be strongly dependent on the size of specimens and the actually observed rate of shrinkage was far greater than the calculated value from the self-diffusion coefficient of atoms. Nabarro ${ }^{8)}$ and Herring ${ }^{9}$, however, suggested that diffusion model was applicable if the lattice vacancies formed at the surface of an inner pore can migrate to and eliminate at grain boundaries as well as the free surface of specimens.

Surveying these theories, Burke ${ }^{10)}$ applied the shrinkage rate equation $\left(\Delta L / L_{0}\right)^{m}=K t\left(\Delta L / L_{0}\right.$ : fractional shrinkage, $m, K$; constant, $t$; time) for the diffusion mechanism to the experimental data by Allison and Murray and found $m=5 / 2$; the value suggesting a,volume diffusion mechanism.

On the other hand, Morgan ${ }^{11)}$ and Yust ${ }^{12)}$ observed several distinct features in non-isothermal sintering of $\mathrm{ThO}_{2}, \mathrm{CaF}_{2}$ and $\mathrm{CeO}_{2}$, which were interpreted with particle rearrangement in combination with grain boundary sliding, defect enhanced diffusion and dislocation slip. Dislocation motion under an ordinary isothermal condition is diffusion controlled because of necessity of the process such as dislocation climb, obstacle removal, or non-conservative dragging of jogs or other irregularities. Dislocation can, however, move without support of the diffusional processes under the extraordinary condition, when thermal stress is accumulated in the powder compact during the initial heating. Thus they adopted the plastic flow mechanism due to slip or rearrangement of dislocation in the beginning of sintering $\mathrm{CaF}_{2}$. Observing a great number of dislocation etch pits close to the weld neck of the joint between two fine single crystals of $\mathrm{CaF}_{2}$, they regarded dislocation slip contributed to shrinkage. Hingorany ${ }^{13)}$ also applied a marker method to see the contribution of plastic flow to shrinkage. $\mathrm{He}$ found that a plastic flow mechanism was responsible for the sintering when a heavy load was applied upon the specimen, while the diffusion mechanism under a light load.

$\mathrm{Kolar}^{14)}$ recently found that active powder compacts (grain size $0.05 \sim 0.1 \mu$ ) initiated to shrink in the temperature range between 400 and $500^{\circ} \mathrm{C}$ where the body with density up to $98 \%$ of the theoretical density was obtained. The density was $90 \%$ at the utmost for less active powder compacts (grain size $1.5 \mu)$. For the initial sintering of these two powder compacts $m \geqq 3$ was observed. Although these results were different from those of Burke $(m=5 / 2)$, detailed discussions were not given by Kolar. It must be noted here that the grain size of the starting materials used by Allison and Murray was in the range between 10 and $50 \mu$ and this was $10 \sim$ 100 times larger than the size used by Kolar.

Through the survey into literatures discussed above the present authors came to the point that a 
volume diffusion process shoud be predominant in coarse powders with the grain size greater than $10 \mu$, while a plastic flow process in fine powders with the grain size less than $1 \%$. If an extremely large shrinkage due to plastic flow mechanism takes place in the first stage, the successive diffusion process might be overlooked in plotting $\log \frac{\Delta L}{L_{0}}$ vs $\log t$. In this mixed process (plastic flow and diffusion) the value of $m$ might be relatively high compared with that in a single diffusional process.

Other studies on the diffusion sintering of $\mathrm{CaF}_{2}$ were performed by Morgan and MacHargue ${ }^{15}$, Haroun et $\mathrm{al}^{16)}$. and Johnson et $\mathrm{al}^{17}$. The selfdiffusion for fluorine ion $\left(\mathrm{F}^{-}\right)$in the $\mathrm{CaF}_{2}$ crystal was investigated by Ure, ${ }^{18)}$ Matzke $^{19)}$ and Barsis and Taylor ${ }^{20)}$, while that for calcium ion $\left(\mathrm{Ca}^{2+}\right)$ by Short and Roy ${ }^{21)}$, Baker et $\mathrm{al}^{22)}$, Beard ${ }^{23)}$ and Matzke and Lindner ${ }^{24)}$.

Although there are many investigations on the sintering of $\mathrm{CaF}_{2}$ as described above, several important problems still remain unclarified on the effect of particle size and adsorbed water, and the ratecontrolling species in diffusion sintering. The present work was undertaken to see those effects by the analysis of shrinkage rate and scanning electron microscopic (SEM) observation.

\section{Experimental}

Calcium fluoride powders used as a starting material were with $99.99 \%$ purity through precipitation out of aqueous solution with HF by Rare Metal Co. Powders with very small grain size were obtained from drying at $100^{\circ} \mathrm{C}$ after precipitation, where the grain size was $0.01 \sim 0.05 \mu$ (by electron microscopic observation) and the amount of adsorbed water was $5 \sim 7 \times 10^{4} \mathrm{ppm}$ (mole fraction) (by KarlFischer titration). The authors denoted the powders as $\alpha$.

The powders denoted as $\beta$, were obtained from drying at $200^{\circ} \mathrm{C}$ for $3 \sim 4 \mathrm{hr}$ after precipitation and were of grain size $0.1 \sim 0.5 \mu$, containing $6 \times 10^{3} \mathrm{ppm}$ (mole fraction) water. The powders $r$ were ones dried at $800^{\circ} \mathrm{C}$ for $3 \mathrm{hr}$ under dewatering atmosphere of reduced pressure $(0.5 \mathrm{mmHg})$ and with grain size of $1 \sim 5 \mu$, containing water less than $3 \times 10^{3} \mathrm{ppm}$ (mole fraction). Absorption of water vapor from air onto the powders $\gamma$ was observed after the several days keeping in desiccator. The electron microscopic photographs of these three types of powders are shown in Figs. 1,2 and 3. These powders were pressed and shaped to pellets with $10 \mathrm{~mm}$ diameter and $4 \mathrm{~mm}$ thickness at the pressure of $1500 \mathrm{~kg} / \mathrm{cm}^{2}$. The overall green densities for $\alpha, \beta$ and $\gamma$ were $1.85 \sim 2.05 \mathrm{~g} / \mathrm{cm}^{3} \quad(58 \sim 65 \%$ of the theoretical density).

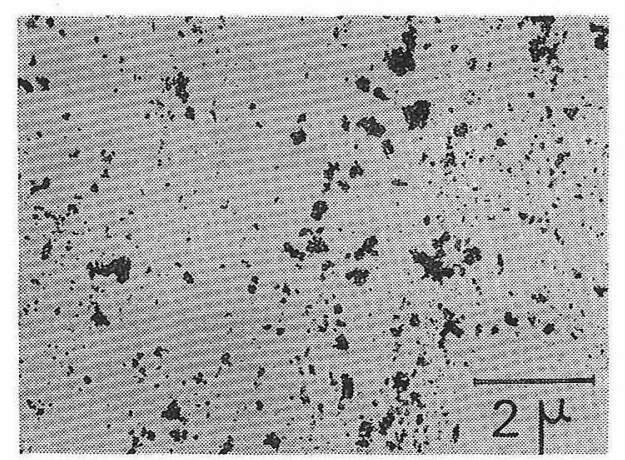

Fig. 1. Starting powders of $\mathrm{CaF}_{2}, \alpha$.

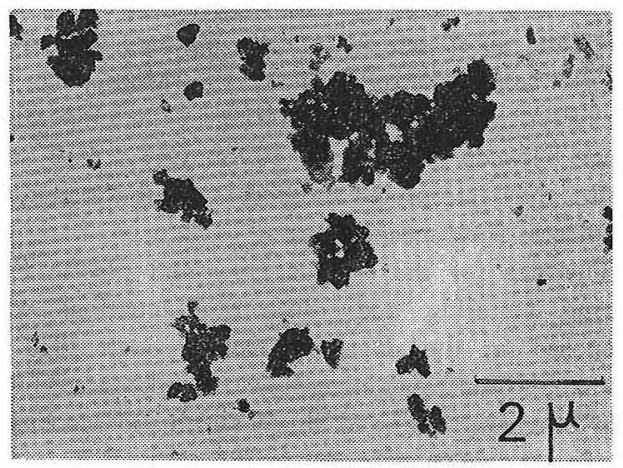

Fig. 2. Starting powders of $\mathrm{CaF}_{2}, \beta$.

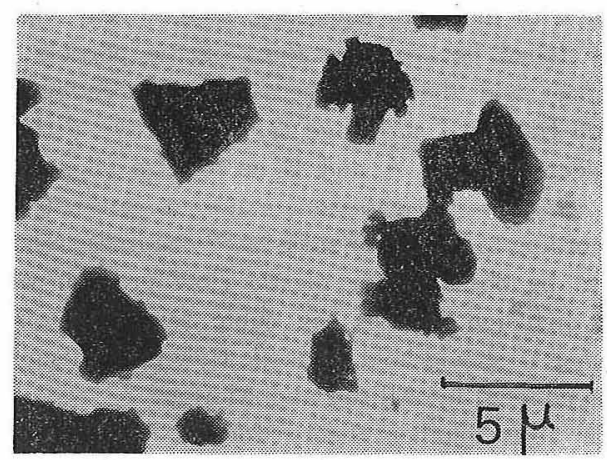

Fig. 3. Starting powders of $\mathrm{CaF}_{2}, \gamma$.

Being sandwitched between two alumina plates, the pellet was placed at the bottom of a silica tube. Silica rod connected with displacement meter was set on it. Weight of the rod was compensated to less than $2 \mathrm{~g} / \mathrm{cm}^{2}$ by an elongation of a spring as shown in Fig. 4. Sintering and measurement of shrinkage were made isothermally in an inert atmosphere of argon gas to prevent samples from oxidation. The temperature reached the desired value $\left(600,700,800,900,1000^{\circ} \mathrm{C}\right)$ within $7 \sim 8$ minutes after inserting the sample into the furnace. The shrinkage rate was monitored by a displacement meter of Shinko Denki Co. type ICM. A correction was made on the data of shrinkage with respect to thermal expansion and actual starting time of sin- 


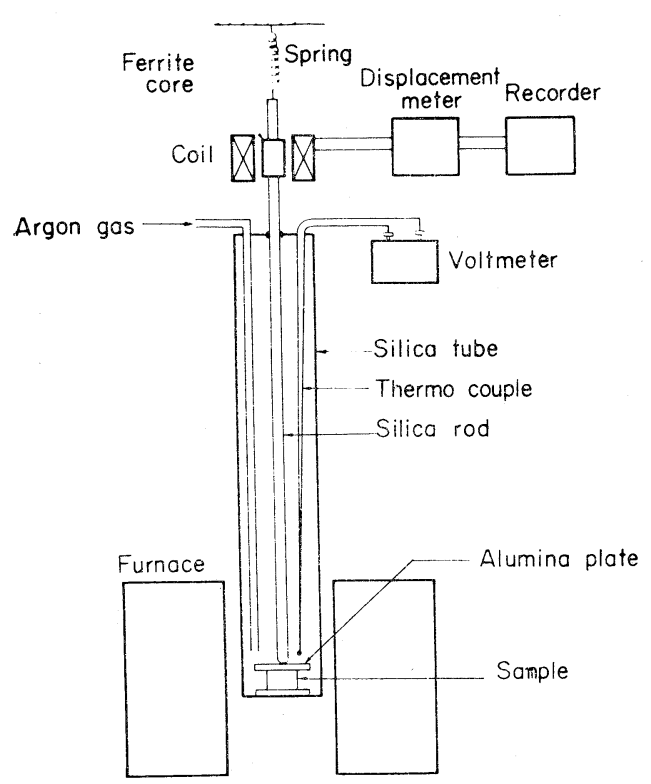

Fig. 4. Apparatus for measuring shrinkage.

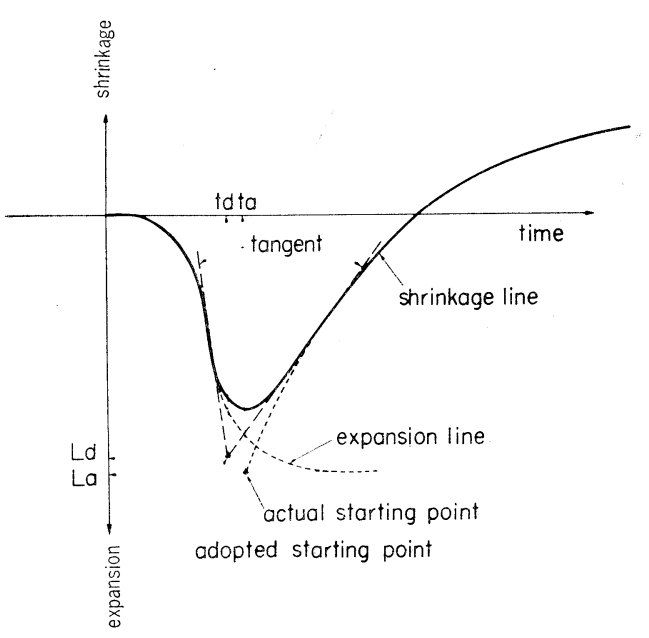

Fig. 5. A correction on the data of shrinkage with respect to thermal expansion and actual starting time of sintering.

tering as shown in Fig. 5. A cross point of each tangent at an inflection point for expansion line and shrinkage line was adopted as a starting point, where the values of $\left|t_{d}-t_{a}\right|$ or $\left|L_{d}-L_{a}\right|$ were negligible small. The scanning electron microscopic observation was made on the fractured surfaces of the specimens on various stages of sintering and under various conditions.

\section{Results}

\subsection{Analysis on the shrinkage rate}

The shrinkage rates of the powder compacts are shown in Fig 6 for the powders $\alpha$ and $\beta$ and in Fig.

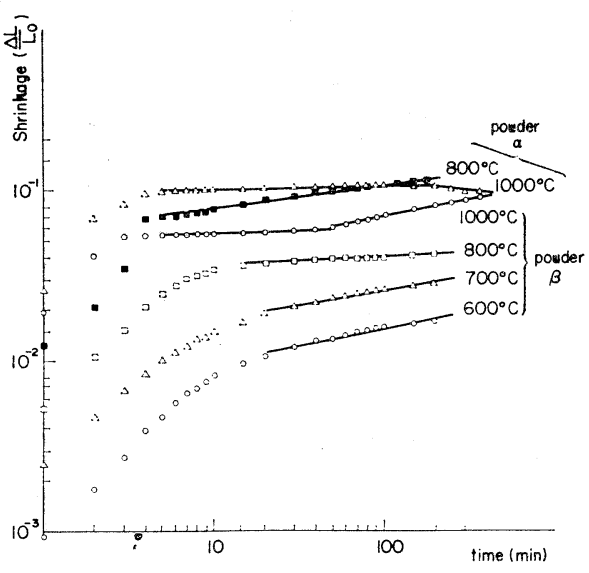

Fig. 6. Log shrinkage-log time plots for sintering of powders $\alpha$ and $\beta$.

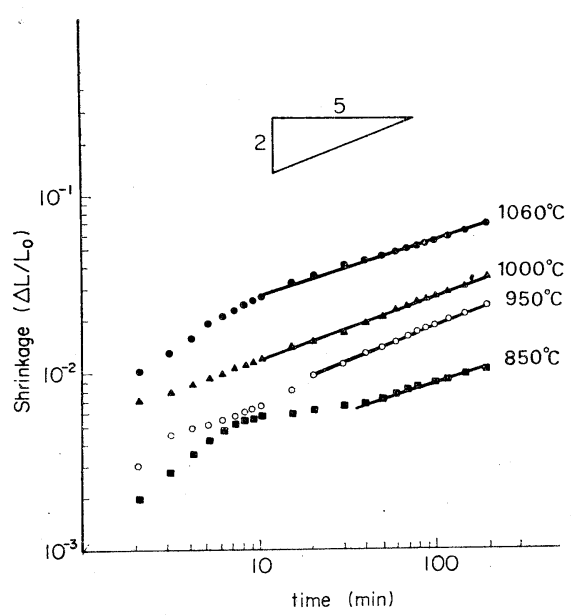

Fig. 7. Log shrinkage-log time plots for sintering of powders $\gamma$.

7 for $\gamma$. For the powders $\alpha$ (grain size $0.01 \sim 0.05 \mu$ ) fractional shrinkage at $1000^{\circ} \mathrm{C}$ was $10 \%$ for the first 10 minutes reaching a steady state in the period from 10 to 100 minutes and finally an expansion of $2-3 \%$ was observed from 100 to 200 minutes. For the powders $\beta$ (grain size $0.1 \sim 0.5 \mu$ ) gradual shrinkage and saturation of shrinkage were observed below $800^{\circ} \mathrm{C}$, while at $1000^{\circ} \mathrm{C}$ a step wise shrinkage took place the grade of shrinkage finally reaching $10 \%$. These behaviors for the powders $\alpha$ and $\beta$ are almost the same as the observation by $\mathrm{Kolar}^{14)}$.

On the other hand the fractional shrinkage for the powders $r$ (grain size $1 \sim 5 \mu$ ) was very small (less than $1 \%$ below $800^{\circ} \mathrm{C}$ and less than $4 \%$ even at $1000^{\circ} \mathrm{C}$ ); and linear shrinkage was found. Application of the diffusional rate equation to the data shown in Fig. 7 gave $m=5 / 2$, suggesting the volume diffusion process above $800^{\circ} \mathrm{C}$. This result corresponds to the finding by Burke $e^{10)}$. 


\subsection{Observation by Seanning Electron Mi- croseope}

The textures in various stages of sintering are shown in Fig. 8, 9, and 10.

1) In case of the powders $\alpha$ and $\beta$;

a) For the ones sintered at $1000^{\circ} \mathrm{C}, 3 \mathrm{~min}$;

Closed pores of $1 \sim 2 \mu$ and several parallel slip bands are found for the sintered bodies of the powders $\alpha$ in Fig. 8-(1), while most of the pores are open for $\beta$ as in Fig. 8-(2).

b) For the ones sintered at $1000^{\circ} \mathrm{C}, 30 \mathrm{~min}$;

Wavy slip bands and closed pores expanded up to several microns are found for $\alpha$ as in Fig. 8-(3), while both open and closed pores are found in $\beta$ as in Fig. 8-(4).

c) For the ones sintered at $1000^{\circ} \mathrm{C}, 6 \mathrm{hr}$;

Slip bands disappeared and closed pores expanded to the size greater than $10 \mu$ for $\alpha$ (Fig. 8-(5)), while many closed pores of $2 \sim 3 \mu$ are observed for $\beta$ (Fig. 8-(6)).

2) In case of the powders $\gamma$;

Sticking of grains during the initial stage of sintering is shown in Fig. 9. No closed pores. are noticed. The slip bands observed in the specimens of $\alpha$, are not found in those of $\beta$ and $r$. This means that the applied stress while fracturing the specimen for scanning electron. microscopic observation has not been the cause
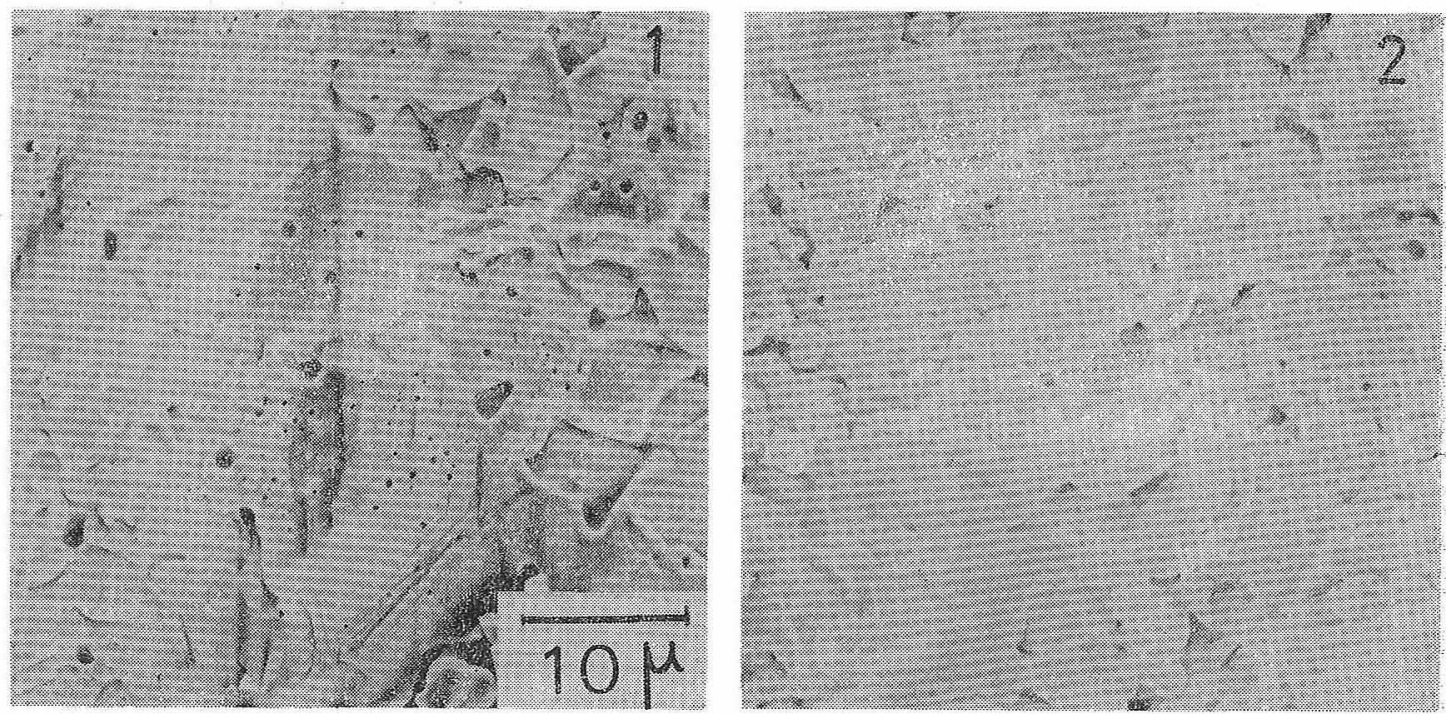

$1000^{\circ} \mathrm{C}, 3 \mathrm{~min}$ in argon
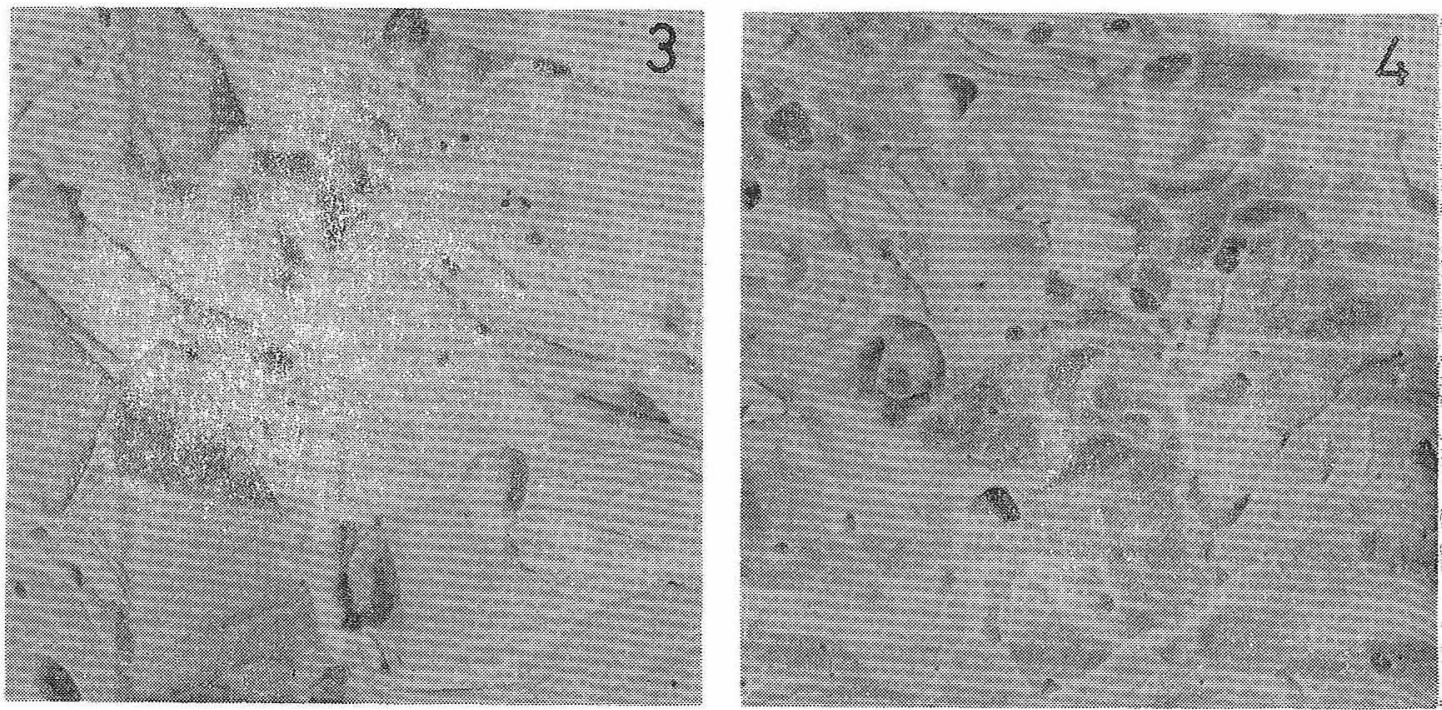

$1000^{\circ} \mathrm{C}, 30 \mathrm{~min}$ in argon 

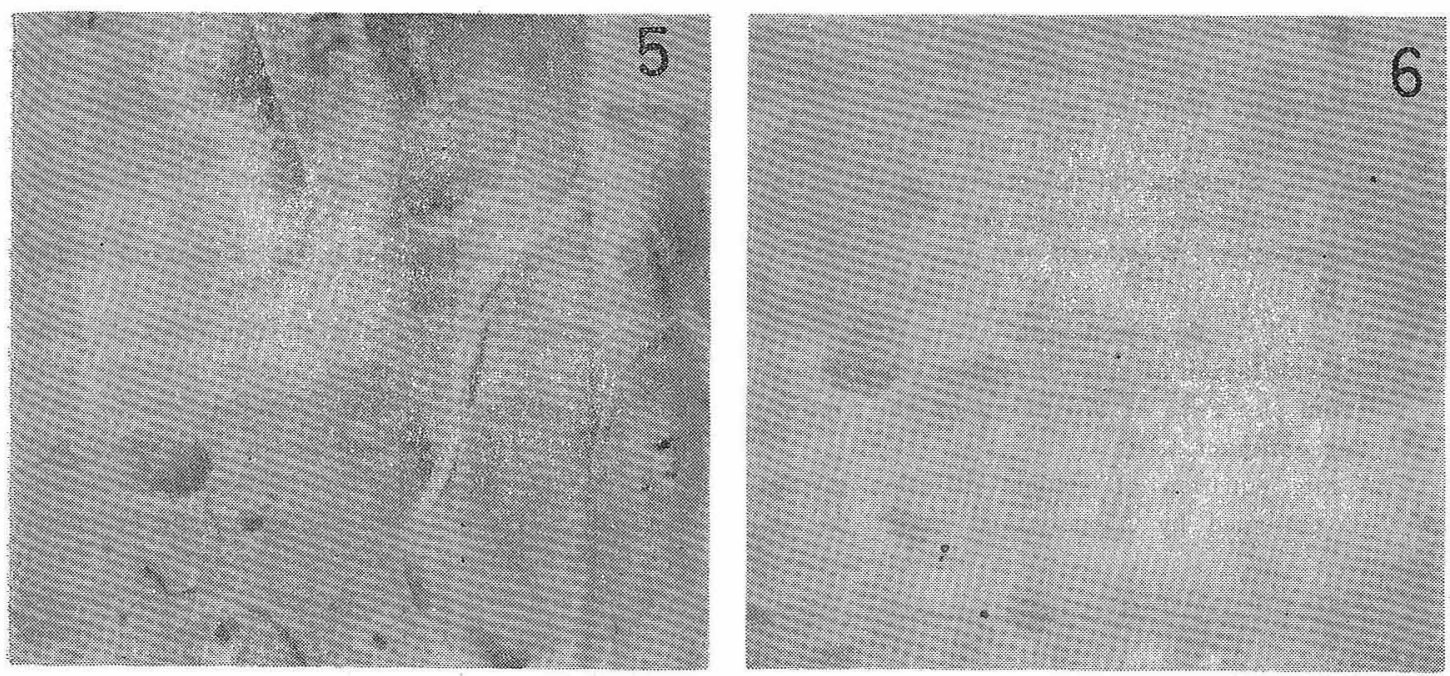

$1000^{\circ} \mathrm{C}, 6 \mathrm{hr}$ in argon

$1,3,5:$ powders $\alpha$

$2,4,6:$ powders $\beta$

Fig. 8. Sintered bodies of $\mathrm{CaF}_{2}$.

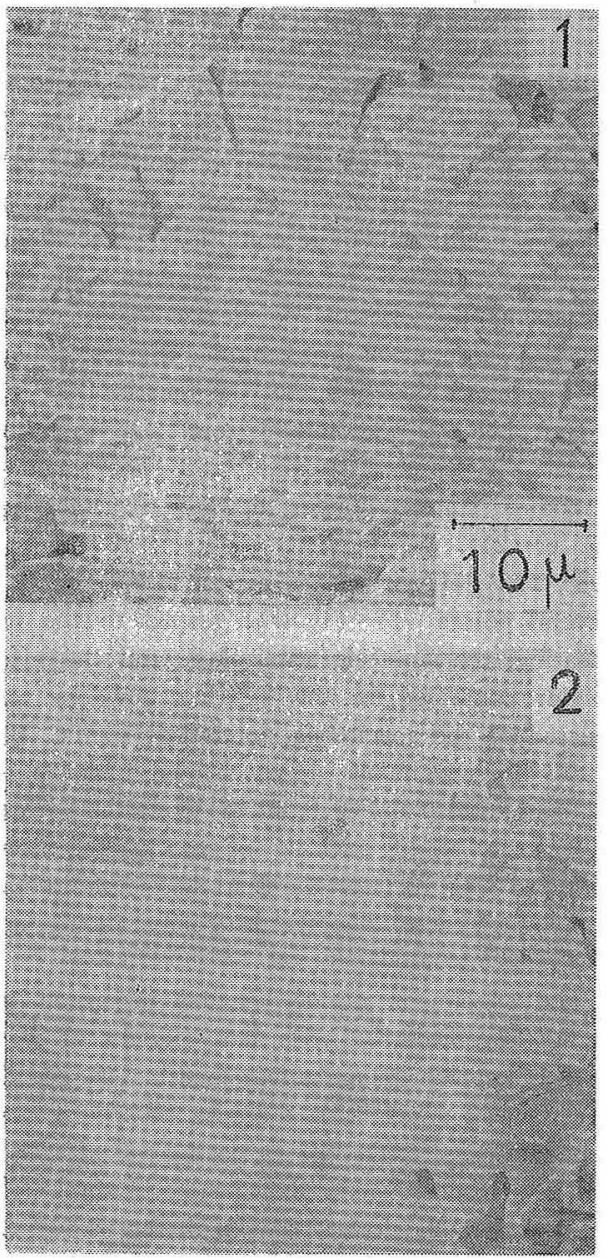

$1: 900^{\circ} \mathrm{C}, 3 \mathrm{hr}$ in argon

$2: 1000^{\circ} \mathrm{C}, 3 \mathrm{hr}$ in argon

Fig. 9. Sintered bodies of $\mathrm{CaF}_{2}$ for powders $\gamma$.
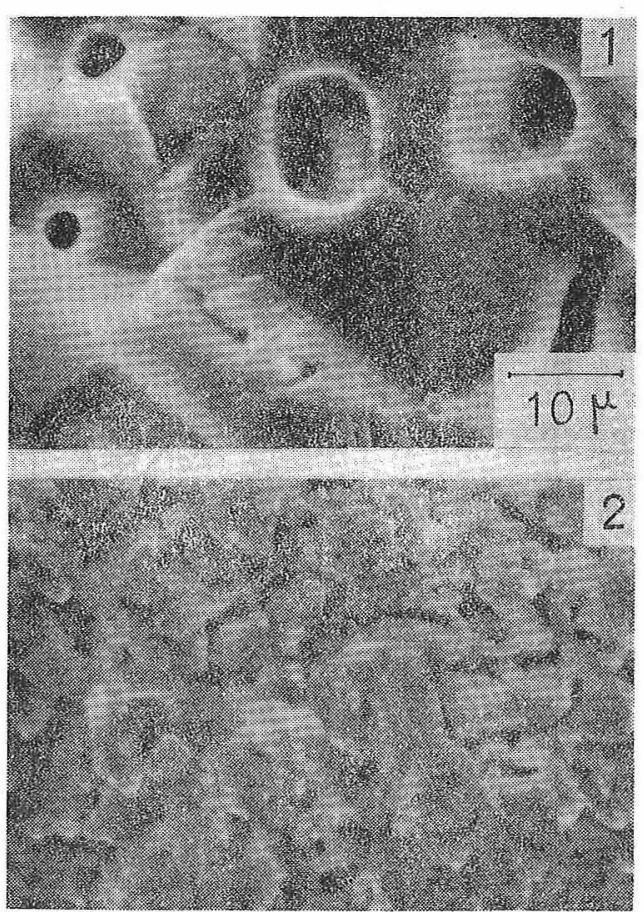

$1:$ in argon

$2:$ under the reauced pressure $(0.8 \mathrm{mmHg})$

Fig. 10. Sintered bodies of $\mathrm{CaF}_{2}$ for powders $\alpha$ (sintered at $1000^{\circ} \mathrm{C}, 6 \mathrm{hr}$ after the slow heating $\left.\left(25^{\circ} \mathrm{C} \rightarrow 1000^{\circ} \mathrm{C}, 6 \mathrm{hr}\right)\right)$.

of those slip bands.

3) The effect of water and rate of raising temperature ;

The $\alpha$ powder compacts were gently heated in argon and under the dewatered atmosphere of reduced pressure $(0.8 \mathrm{mmHg}$ ) (6 hours were 
spent from $25^{\circ} \mathrm{C}$ to $1000^{\circ} \mathrm{C}$ ) in order to examine the effect of water contained in the powders and also the effect of heating rate.

The textures of those specimens are shown in Fig. 10. Sintering did not proceed in the specimen heated under the dewatered atmosphere (Fig. 10-(2)).

\section{Discussion}

\subsection{Calculation of self-diffusion coefficient} from the rate of sintering of the $\gamma$ powder compact.

The rate equation of volume diffusion giving $m=5 / 2$ presented by Kingery and Berg $^{25)}$ is as follows,

$$
\left(\frac{\Delta L}{L_{0}}\right)^{5 / 2}=\frac{20 \sigma \delta D_{t}}{2 r^{3} k T}
$$

Where $\Delta L / L_{0}$; fractional shrinkage, $\sigma$; surface energy $\left(=500 \mathrm{erg} / \mathrm{cm}^{2}\right), \delta^{3} ;$ volume of a vacancy $(=4.1 \times$ $\left.10^{-23} \mathrm{~cm}^{3}\right), D$; diffusion coeff., $r$; radius of the grain $\left(=2.0 \times 10^{-4} \mathrm{~cm}\right), k$; Boltzma const. $\left(=1.38 \times 10^{-16}\right.$ $\left.\mathrm{erg} /{ }^{\circ} \mathrm{C}\right)$, and $T$; absolute temperature, $t$; time.

The calculated values of $D$ are shown in Fig. 11 . One may easily find those values of the self-diffusion coefficients calculated from sintering correspond

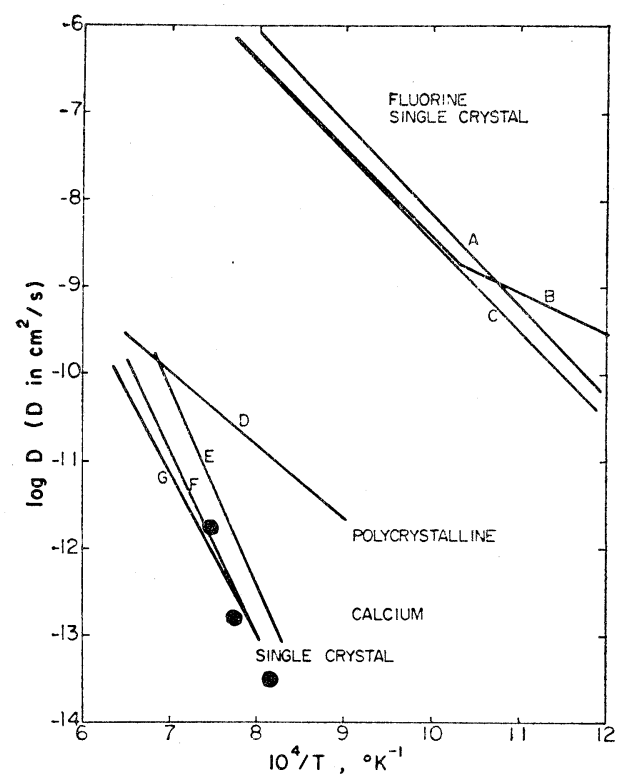

A : Ure (18)

B : Matzke (19)

C : Barsis and Taylor (20)

D : Short and Roy (21)

$\mathrm{E}:$ Baker and Taylor (22)

F : Beard (23)

$\mathrm{G}:$ Matzke and Lindner (24)

Fig. 11. Diffusion coefficients in $\mathrm{CaF}_{2}$ vs $1 / T$ determined by sintering compared with those for $\mathrm{F}^{-}$and $\mathrm{Ca}^{2+}$ determined by ionic conductivity $(\mathrm{A}, \mathrm{C})$ and tracer (B,D,E,F,G). to those of $\mathrm{Ca}^{2+}$ tracers in $\mathrm{CaF}_{2}$ single crystals. The textures of the specimens of $\gamma$ in. Figs. 9-(1) and $9-(2)$ is consistent with diffusional process. A volume diffusion process rate-controlled by $\mathrm{Ca}^{2+}$ is, therefore, concluded to be responsible for sintering of the coarse powders $r$.

\subsection{Processes for an initial sintering of the fine powders $\alpha$.}

According to the study on the creep of $\mathrm{CaF}_{2}$ polycrystalline by Pratt ${ }^{26)}$, creep process proceeds with a change of slip bands from parallel type to wavy one. Groves ${ }^{27)}$ reported that plastic flow easily take place at $200 \sim 400^{\circ} \mathrm{C}$ for fluorite structure crystals. Because the crystals with the $\mathrm{CaF}_{2}$ type symmetry has three independent slip systems as the one $\{001\}$ $\langle 1 \overline{1} 0\rangle$ and two others as $\{110\}<1 \overline{1} 0\rangle$ respectively. Many slip bands observed in the initial sintering of the powders $\alpha$ (Fig. 8-(1) and Fig. 8-(3)) are similar to those found in the creep process of $\mathrm{CaF}_{2}$ polycrystalline samples by Groves. Particularly, the behaviors of slip bands changing from parallel multi-bands in Fig. 8-(1) to wavy ones in Fig. 8-(3) are quite similar to that of dislocation rearrangement in creep process of $\mathrm{CaF}_{2}$ polycrystalline samples. Based upon these findings, plastic flow due to rearrangement of dislocation was considered to be mainly responsible for the initial sintering of the powders $\alpha$. Although more complicated mechanisms could be considered for these vigorous sintering processes in the very fine powders containing water as $\alpha$, the observation by scanning electron microscope makes us convince that the plastic flow mechanism played a predominant role. On the other hand these types of slip bands were not found in the bodies sintered under dewatered atmosphere (Fig. 10-(2)).

\subsection{The effect of water on sintering}

Several points $(1) \sim(4)$ with respect to the rate of heating, the sintering atmosphere and the effect of water contained in the starting powders were discussed on the specimens sintered at $1000^{\circ} \mathrm{C}, 6 \mathrm{hr}$. 1) For the specimens slowly heated under a dewatered atmosphere $(0.8 \mathrm{mmHg})$ using the powders $\alpha$, only a slight sticking of the particles was observed (Fig. 10-(2)), the final degree of sintering (apparent density/theoretical density) being only $69 \%$.

2) The specimens rapidly heated in argon gas using the powders $\beta$ with less amount of water than $\alpha$ kept shrinkage up to the final stage (Fig. 6 ). Closed pores with the size of $2 \sim 3 \mu$ were found (Fig. 8-(6)).

3) For the specimens slowly heated in argon using the powders $\alpha$, closed pores with the size of $3 \sim$ $10 \mu$ were found (Fig. 10-(1)), where the final degree of sintering achieved was $85 \%$.

4) For the specimens rapidly heated in argon using 
Table. 1 Summary of the effects of particle size and sorpted water on sintering of calcium fluoride

\begin{tabular}{|c|c|c|c|c|}
\hline & \multicolumn{2}{|c|}{ Starting powder } & \multicolumn{2}{|c|}{ Sintering } \\
\hline & particle size & $\begin{array}{l}\text { sorpted water } \\
\text { (mole fraction) }\end{array}$ & initial stage & medium or final stage \\
\hline$\alpha$ & $0.01 \sim 0.05 \mu$ & $5 \sim 7 \times 10^{4} \mathrm{ppm}$ & $\begin{array}{l}\text { Rapid shrinkage, } \\
\text { closed pores of } 1 \sim 2 \mu \\
\text { lots of slip bands } \\
\text { plastic flow process }\end{array}$ & $\begin{array}{l}\text { an expansion of specimen } \\
\text { an expansion of closed pores more than } \\
10 \mu \\
\left(\begin{array}{l}\text { closed pores of } 3 \sim 10 \mu \\
\text { in case of gently } \\
\text { heating }\end{array}\right)\end{array}$ \\
\hline$\beta$ & $0.1 \sim 0.5 \mu$ & $6 \times 10^{3} \mathrm{ppm}$ & $\begin{array}{l}\text { rapid shrinkage, } \\
\text { open pores and closed pores less than } \\
1 \mu\end{array}$ & $\begin{array}{l}\text { step-wise shrinkage } \\
\text { closed pores of } 2 \sim 3 \mu\end{array}$ \\
\hline$r$ & $1 \sim 5 \mu$ & $\begin{array}{l}\text { less than } \\
3 \times 10^{3} \mathrm{ppm}\end{array}$ & $\begin{array}{l}\text { gradual shrinkage, } \\
\text { open pores, } \\
\text { volume diffusion process rate-controlled } \\
\text { by } \mathrm{Ca}^{2+}\end{array}$ & $\begin{array}{l}\text { gradual shrinkage continues } \\
\text { open pores }\end{array}$ \\
\hline
\end{tabular}

the powders $\alpha$, closed pores with the size of greater than $10 \mu$ (sometimes up to $20 \sim 30 \mu$ ) were found (Fig. 8-(5)). This means that the expansion and mutual merging of close pores have been made on the final stage of sintering. Apparent expansion was also observed on the final stage of shrinkage measurement as shown in Fig. 6, where the final degree of sintering was $85 \sim 90 \%$.

The effect of water was also observed in the initial sintering of the powders $r$ besides the points $(1) \sim(4)$. Initial sintering for the powders $r$ containing water to some extent after the several days of keeping in the desiccator showed rather rapid shrinkage and non-volume diffusion process, where the detailed mechanism is still unclarified. It is surely remarked that water enhanced the initial shrinkage even for coarse powders. From the discussion above the points are summarized as follows.

a) Adsorbed water enhanced the rate of initial sintering for both fine and coarse powders.

b) The larger closed pores were found for the powders containing the more amount of water.

c) The size of closed pores for the specimen heated slowly was less than that for those heated rapidly $(3-10 \mu$ vs. the size greater than $10 \mu)$. This means that the water had been liberated from the specimens to some extent during heating before the sintering process took place.

These points a), b) and c) are still summaried as follows. Although water enhanced the rate of initial sintering of $\mathrm{CaF}_{2}$, it became trapped within a specimen. This was the cause of expansion of closed pores during sintering. Densification was thus hindered on the final stage.

\section{Conclusion}

The effect of particle size and adsorbed water was examined upon the sintering process of $\mathrm{CaF}_{2}$. For the sintering of coarse powders was responsible the volume diffusion mechanism rate-controlled by diffusion of $\mathrm{Ca}^{2+}$ ions. The plastic flow due to dislocation rearrangement was responsible for the initial sintering process of fine powders. Water enhanced the rate of initial sintering, while the water enclosed within the powder compact gave rise to expansion of closed pores on the final stage of sintering. These are shown in Table 1.

\section{Acknowledgement.}

This work was financially supported by the Ministry of Education.

\section{References}

1) E.B. Allison and P. Murray, Acta Metallurgica 2487 (1954).

2) J. Frenkel, J. Tech. Phys. (Moscow), 9, 5(1945).

3) P.W. Clark, J. White, Trans. Brit. Ceram. Soc., 52. 1 (1953).

4) J. Mackenzie, R. Shutlleworth, Proc. Phys. Soc. (London) 62, B, 833 (1949).

5) Conyers Herring,J. Appl. Phys., 21, 301 (1950).

6) B.Ya. Pines, J. Tech. Phys. (U.S.S.R.), 16, 737 (1946).

7) G.C. Kuczynski, Trans. AIME, 185, 169 (1949).

8) F.R. Nabarro, "Report of a Conference on Strength of Solids”, Phys. Soc. London p. 75. (1948).

9) Conyers Herring, J. Appl. Phys., 21, 437 (1950).

10) J.E. Burke, "Ceramic Fabrication Processes"(ed. W.D. Kingery, New York, Chapman and Hall, London, p. 120. (1958).

11) C.S. Morgan and C.S. Yust, J. Nucl. Mat. 10 182-190 (1963).

12) C.S. Yust and C.S. Morgan, Trans. Met. Soc. AIME 2361504 (1966).

13) A.R. Hingorany, F.V. Lenel and G.S. Ansell "Materials Science Research", Edited by T.J. Gray and V.D. Frechette, Plenum Press New York, vol. 4. (1969). p. 375-91.

14) D. Kolar and M. Trontelj. Phys. Sintering 1, 0.10.17 (1969). 
15) C.S. Morgan and C.J. McHargue, Phys. Sintering, 2 [2] 55-70 (1970).

16) N.A. Haroun, M.S. Abdel-Azim, and G.I. Orabi, J. Am. Ceram. Soc., 54 [12] 640 (1971).

17) D.Lynn Johnson, J. Am. Ceram. Soc. 55 [6] 327.

18) R.W. Ure, Jr., J. Chem. Phys., 26 [6] 1363 (1957).

19) Hansjoachim Matzke, J. Mater. Sci., 5 [10] 831-36 (1970).

20) E. Barsis and A. Taylor, J. Chem. Phys., 45 [4] 1154 (1966).

21) J.M. Short and Rustum Roy, J. Phys. Chem., 68. [10] 3077 (1964).
22) M.E. Baker and Abraham Taylor, J. Phys. Chem. Solids, 30 [ 4] 1003 (1969).

23) M.F. Beard, J. Am. Ceram. Soc., 54 [3] 144 (1971).

24) Hansjoachim Matzke and Roland Lindner, $Z$. Naturforsch. A, 19, 1178 (1964).

25) W.D. Kingery and M. Berg. J. Appl. Phys., 26, 1205 (1955).

26) P.L. Pratt, C. Roy, and A.G. Evans, "Materials Science Research," Edited by W.W. Kriegel and H. Palmour vol. 3, 225 (1964).

27) G.W. Groves and A. Kelly. Phil. Mag. 8, 877 (1963).

[Received August 10, 1974]

\title{
弗化カルシウムの焼結における粒径及び吸着水分の効果
}

\author{
水田進*・柳 田 博 明 \\ (東京大学工学部工業化学科, * 現在, 東京工業試験所)
}

弗化カルシウムの焼結機構に関する従来の研究は，互 いに矛盾しているように見えるので，とくに粒径の効果 について着目し検討を加えた. 弗化カルシウム粉体充填 物の $800 \sim 1000^{\circ} \mathrm{C}$ の温度範囲での等温収縮を測定し, 焼 結体の走查型電顕による観察をおこなった，粗粒子(1〜 $5 \mu)$ については体積拡散機構が成立つ、収縮速度から計 算した拡散係数は, 単結晶中での $\mathrm{Ca}^{2+}$ トレーサーの值
とほぼ一致した。莖部成長と開気孔が顕微鏡写真中に認 められた. 微粒子 $(0.01 \sim 0.05 \mu)$ の初期焼結に対して は, 格子転位の再編成による塑性流動機構が成立つ. ス リップバンドと閉気孔が認められた。微粒子表面の吸着 水分は, 初期焼結を促進したが, 終期段階で閉気孔の膨 脹をひき起した。

$(8 / 10 / 1974$ 受付 $)$ 